\title{
Kepribadian Negosiator
}

\author{
Yusuf Hamdan
}

ABSTRACT

Negotiation has an important role on human interaction in order to fulfill their needs of life. Negotiation enabled cooperation and in turn, resolved conflicts as well. This paper examines a vital part of negotiation, namely negotiator's personality. Although tactic and strategy are important, the negotiator's personality played a more vital role. A good tactic and strategy will be useless in the hands of negotiator whose personality isn't matched perfectly with negotiation purposes. The description toward negotiator personality covered a discussion toward negotiator's attitude, and confidence.

Kata kunci: negosiator, negosiasi, kepribadian personal

\section{Pendahuluan}

Negosiasi saat ini telah menjadi kebutuhan manusia hampir di segala bidang. Banyak orang berhasil memeroleh kesuksesan karena kemampuan negosiasi mereka. Roger Dawson seorang pakar negosiasi, bahkan berani mengatakan bahwa negosiasi merupakan satu alat untuk memeroleh uang yang paling cepat dibandingkan dengan cara yang lain, 'you'll never make money faster then when you're negotiating. "Pendapat tersebut menekankan begitu besar peran negosiasi dalam mencapai keberhasilan.

Sebagaimana ditulis Purwadarminta dalam Kamus Umum Bahasa Indonesia (KUBI), negosiasi berarti, "proses tawar-menawar dengan jalan berunding untuk memberi atau menerima guna mencapai kesepakatan bersama antara satu pihak (kelompok atau organisasi) dan pihak (kelompok atau organisasi) yang lain" (Purwadarminta, 1997:686). Dari pengertian ini dapat diketahui beberapa ciri pokok negosiasi, yaitu: negosiasi itu merupakan proses tawar-menawar. Dapat dikatakan, tidak ada negosiasi tanpa tawarmenawar; dilakukan dengan jalan berunding. Artinya, negosiasi merupakan proses sosial yang bersifat damai, menjauhi segala tindakan kekerasan. Mengutamakan persuasi daripada koersi; pihak yang bernegosiasi saling memberi dan menerima (konsesi) agar dicapai kesepakatan. Pencapaian kesepakatan merupakan tujuan utama diselenggarakannya negosiasi. Tanpa kesepatan, negosiasi yang berjalan baik dan menyenangkan sekalipun dipandang sebagai negosiasi yang tidak efektif; negosiasi merlibatkan pihak-pihak untuk saling bekerjasama atau untuk menyelesaikan konflik.

Sebagai proses sosial yang memiliki ciri-ciri seperti itu, negosiasi menuntut negosiator memiliki kepribadian yang cocok untuk melakukannya secara berhasil. Seperti ditegaskan oleh Lewicki et al., kepribadian penting dalam negosiasi karena, 
"individual tend to view the actions of other parties through a lens of personality" (Lewicki et al., 2003:377).

Siapakah yang memiliki ciri-ciri kepribadian yang cocok untuk menjadi negosiator? Aspek kepribadian apa saja yang perlu mendapat perhatian negosiator?

Pemahaman mengenai sifat-sifat pribadi negosiator penting untuk dikaji, karena pengetahuan demikian masih kurang disebabkan masih jarang dikaji dan diteliti. Kajian yang semakin sering dan luas mengenai kepribadian negosiator akan memberi manfaat nyata dalam mengembangkan khazanah pengetahuan tentang negosiasi, dan memberi manfaat praktis bagi mereka yang ingin membina diri menjadi negosiator yang berhasil. Secara singkat, dapat dikatakan, segala taktik dan strategi negosiasi yang ulung menjadi tidak berarti di tangan pribadi yang tidak memiliki ciri-ciri negosiator yang baik.

Tulisan ini ditujukan untuk menjelaskan segisegi kepribadian yang cocok dikembangkan bagi orang yang berhasrat membina diri sebagai negosiator yang baik dan berhasil yang terdiri dari: (1) karakteristik personal yang harus dimiliki negosiator; (2) sikap yang harus dikembangkan negosiator; dan (3) keyakinan yang harus dimiliki negosiator.

Dengan ini diharapkan siapa yang tertarik menapaki karier sebagai negosiator akan memeroleh bekal untuk menyiapkan diri menuju negosiator profesional. Bahasannya meliputi karakteristik personal negosiator, sikap negosiator, dan keyakinan negosiator.

\section{Pembahasan}

\subsection{Karakteristik Personal Negosiator}

Roger Dawson dalam bukunya Secreets of Power Negotiationg, Rahasia Sukses Seorang Negosiator Ulung (2002:349-364) menjelaskan aspek kepribadian yang harus menjadi perhatian adalah karakteristik personal yang harus dimiliki seorang negosiator. Menurut Dawson, karakteristik itu terdiri dari: (1) keinginan untuk menggali lebih banyak informasi; (2) kesabaran untuk bertahan lebih lama dari negosiator lawan; (3) keberanian untuk meminta lebih; (4) integritas untuk menekan demi solusi menang-menang; serta (5) kesediaan untuk menjadi pendengar yang baik (Dawson, 2002:351-354).

Negosiator yang baik harus memiliki keinginan dan semangat terus bertanya untuk menggali informasi lebih banyak dari pihak lawan agar mengetahui lebih baik dan mempertanyakan kembali berbagai asumsi yang dimilikinya mengenai siapa lawan itu (Dawson, 2002:351). Sifat ini mendorong negosiator melakukan investigasi mengenai apa dan dengan siapa dia akan atau sedang bernegosiasi.

Bernegosiasi adalah proses berkomunikasi, saling mendengarkan pendapat untuk mencapai sebuah persetujuan. Komunikasi, demikian menurut Fisher, et al. (2000:37) "meski terjadi antara dua pihak dengan latar belakang dan tata nilai yang sama, tidak otomatis mudah dilakukan." Negosiator perlu menggali informasi dengan mengambil langkah-langkah, yaitu: menciptakan kondisi yang tepat, mengusahakan agar skala waktunya tepat, menyiapkan dan mengemukakan informasi secara efektif, mendengarkan secara efektif, dan mengatasi hambatan "bahasa kedua" (Scott, 1985:84).

Dengan menggali informasi lebih banyak dapat dibangun iklim negosiasi yang ramah dan produktif sehingga negosiasi mengarah kepada dicapainya kerjasama (Scott, 1985:12-13). Di antara yang penting untuk digali adalah pesan-pesan nonverbal selama negosiasi (lihat Scott, 1985:14; Pease, 1996:4; dan Tubbs dan Moss, 1996:113).

Negosiator yang baik harus juga memiliki sifat sabar untuk bertahan lebih lama dari negosiator lawan. Kesabaran adalah hal yang menguntungkan bagi seorang negosiator (Dawson, 2002:352). Kesabaran negosiator berkaitan dengan daya tahannya terus-menerus memberi informasi kepada pihak lain untuk menumbuhkan pemahaman mengenai apa yang disampaikan, dan bersabar dalam menyimak segala apa yang disampaikan pihak lain.

Dawson (2002:352) menjelaskan negosiator yang baik akan sabar dan tidak membiarkan tekanan waktu menggiringnya membuat kesepakatan yang 
bukan kepentingan terbaik bagi setiap pihak. Dia mencontohkan bagaimana diplomat Vietnam, Xuan Thuy, menyewa sebuah vila di pinggir kota untuk waktu dua setengah tahun; sedangkan lawannya Averell Harriman diplomat Amerika, menyewa suite room di di Hotel Ritz Paris dalam hitungan minggu dalam perundingan tentang perang Vietnam.

Dalam negosiasi, sudah biasa terjadi perang urat-saraf. Situasi dirancang demikian rupa agar rnegosiator tidak nyaman, sehingga tanpa sadar ingin segera mengakhiri negosiasi (lihat Fisher, et al., 2000:158). Konsesi yang diperoleh negosiator lebih banyak diperoleh pada penghujung proses negosiasi. Negosiator buruk meninggalkan ruangan sebelum negosiator lawan karena tidak bisa lagi sabar menghadapi negosiator lawan yang bertele-tele.

Kakakteristik kepribadian lain yang harus dimiliki negosiator adalah keberanian meminta lebih banyak dari yang diharapkan. Menurut Dawson (2002:353), ini salah satu karakteristik terpenting negosiator. Dia tidak boleh takut atau malu meminta lebih dari yang diharapkan, karena khawatir diejek pihak lain.

Dawson mengutip Kissinger yang berpendapat bahwa "efektivitas konferensi tergantung pada pernyataan tuntutan seseorang." Menyatakan posisi kemungkinan maksimum yang mungkin diperoleh, kadang-kadang sulit dilakukan. Seseorang mungkin takut atau tidak percaya diri untuk menyatakan pernyataan penawarannya. Negosiator yang baik harus mengatasi rasa takut itu, dan berani untuk menyatakan posisi kemungkinan maksimum yang akan diterimanya.

Pedoman untuk bernegosiasi demi keuntungan kita adalah mulai dengan penawaran yang tertinggi yang dapat dipertahankan. Penawaran awal perlu 'yang paling tinggi', karena menentukan batas tertinggi yang dapat diraih dan memberi ruang gerak yang leluasa selama tawarmenawar" (Scott, 1985:129). Penawaran harus dilakukan dengan tegas, jelas, tanpa permintaan maaf, atau ragu-ragu.

Ciri lain kepribadian negosiator adalah memiliki integritas untuk menekan demi solusi menang-menang. Negosiator harus mendorong pihak lain dan diri sendiri untuk tercapainya solusi menang-menang. Menurut Dawson (2002:354355), negosiastor harus jujur dan tulus dalam bernegosiasi serta tetap kukuh kepada kesepakatan yang menguntungkan semua pihak tanpa harus mengorbankan diri sendiri. Seperti yang ditekankan oleh Cohen (1980:221), dalam menjalankan negosiasi hendaknya diarahkan kepada tercapainya kepuasan bersama yang membuat setiap pihak merasa menang. Godaan untuk membelokkan ke arah keuntungan salah satu pihak selalu muncul dalam setiap negosiasi.

Negosiator yang baik, menurut Dawson, harus bersedia menjadi pendengar yang baik. Dalam pandangan Dawson (2002:354), hanya pendengar yang baik yang dapat menjadi negosiator menangmenang. Tanpa itu, berempati kepada pihak lain menjadi muskil.

Menurut Fisher dkk. (2000:39-40), negosiator perlu mendengarkan dengan aktif dan memperhatikan ucapan pembicara lain. Mendengar secara aktif, meningkatkan kemampuan seseorang, tidak hanya memahami sejauh yang didengar, tetapi juga apa yang mereka maksudkan. Standar teknis untuk menjadi pendengar yang baik adalah menunjukkan perhatian atas penjelasan yang disampaikan, memintanya sekali lagi untuk menjabarkan maksudnya dengan lebih jelas, dan mengulang penjelasannya atas beberapa bagian yang mungkin membingungkan atau tidak jelas.

Kegiatan mendengarkan merupakan suatu proses interaktif. Hal ini perlu didukung dengan penggunaan bahasa tubuh, misalnya dengan mencondongkan badan ke depan, memiringkan kepala sebagai tanda seseorang tengah memperhatikan, memberikan pertanyaan, atau memberi umpan balik, memusatkan perhatian pada apa yang diucapkan, bukan pada bagaimana ia menuturkannya, meningkatkan pemahaman mengenai apa yang dibicarakan dengan melakukan pencatatan segera setelah pembicaraan dimulai. Semua itu dilakukan untuk memberi tanda bahwa seseorang peduli pada apa yang dikatakan pihak lawan.

Dawson (2002:355) menyarankan untuk memahami yang dikemukakan pihak lain, 
hendaknya meminta pihak lain untuk menyatakan kesimpulannya terlebih dahulu. Kemudian, jika tidak setuju dengan kesimpulannya, mintalah agar mereka memberikan pernyataan-pernyataan yang bisa mendukung kesimpulannya.

\subsection{Sikap Negosiator}

Negosiator yang baik harus mengembangkan sikap yang sesuai dengan kepribadian seorang negosiator. Mengenai sikap, Dawson (2002:357) menjelaskan negosiator yang baik: (1) harus bersedia hidup dalam ambiguitas; (2) memiliki semangat untuk bersaing; (3) tidak memiliki kebutuhan yang kuat untuk disukai orang lain.

Negosiator harus terbiasa hidup dalam ambiguitas. Menikmati ketidakkepastian yang belum memberi kemenangan atau kekalahan. Negosiator harus suka bergaul dengan orang dari pada benda-benda mati. Negosiator harus dapat memperkirakan dan menerima situasi yang tidak terduga.

Selain itu, negosiator harus memiliki semangat bersaing yang tinggi. Menurut Dawson (2002:358), negosiator harus memiliki semangat untuk menang dan tertarik kepada situasi negosiasi yang memberikan kesempatan untuk menguji keyakinan dan kemampuannya. Memperlakukan negosiasi sebagai permainan yang mengasyikan sekaligus memberi imbalan yang memadai atas upayanya memenangkan pertandingan. Seorang negosiator pada dasarnya mestilah seorang kompetitor, bersedia untuk bersaing dengan siapa saja untuk menjadi yang terbaik. Seorang wiraniaga yang mampu memainkan permainan olah raga dengan baik, mungkin mengalami ketakutan ketika menangani pembeli. Hal ini dapat diatasi, antara lain, dengan melatih diri untuk mampu menempatkan negosiasi sebagai permainan yang kompetitif seperti halnya dalam olah raga.

Negosiator yang baik harus mengembangkan sikap yang independen, tidak boleh memiliki kebutuhan yang kuat untuk disukai orang lain. Negosiator memang harus disukai orang lain. Namun, keinginan yang tinggi atau berlebih untuk disukai orang lain dapat berubah menjadi kelemahan yang bisa dimanfaatkan pihak lawan.

\subsection{Keyakinan Negosiator}

Mengenai keyakinan yang harus dimiliki negosiator, Dawson menekankan tiga hal: (1) negosiasi selalu merupakan hubungan dua arah; (2) negosiasi dimainkan dengan seperangkat aturan; (3) 'tidak' merupakan sebuah posisi negosiasi pembuka.

Negosiator yang baik memiliki keyakinan bahwa negosiasi merupakan proses dua arah. Negosiasi akan berjalan baik jika pihak-pihak merasakan adanya prospek yang positif dalam proses yang sedang mereka jalankan. Hasil-hasil yang dicapai akan mendatangkan keuntungan kepada kedua belah pihak yang bernegosiasi.

Negosiator selalu merasakan tekanan dalam proses negosiasi. Namun demikian dia yakin, bahwa selain dirinya, pihak lain juga ada dalam tekanan untuk mencapai kesepakatan. Seorang peminjam uang dari bank jangan terlalu memasalahkan dirinya yang perlu uang, karena sesungguhnya pengelola bank juga dalam tekanan untuk mendapatkan peminjam uang. Setiap orang tahu dan merasakan tekanan pada dirinya tapi tidak tahu dan tidak merasakan tekanan pada diri orang lain.

Negosiator harus yakin bahwa negosiasi merupakan proses yang dilaksanakan berdasarkan seperangkat aturan. Seperti bermain catur, buah catur tidak dapat dimainkan sesuka hati. Strategi dan taktik yang umum diketahui dan berjalan dalam berbagai situasi dan tempat, semestinya menjadi satu pengetahuan yang menjadi dasar keyakinan negosiator tentang bagaimana negosiasi yang baik dapat diselenggarakan. Kalau negsiator ragu akan keberlakuan aturan-aturan itu, mungkin hanya faktor waktu dan pengalaman saja yang akan menambah keyakinan.

Keyakinan negosiator yang ketiga yang dijelaskan Dawson adalah bahwa 'tidak' merupakan posisi pembuka dalam negosiasi. Bagi negosiator yang baik, 'tidak' dipandang sebagai permulaan proses, bukan sebagai penolakan. Jika pihak lain menolak mentah-mentah proposal seorang negosiator, dia tidak akan marah kemudian membalas dengan taktik negosiasi yang emosional, melainkan dia akan memahaminya sebagai posisi 
awal dan akan mencari tahu mengapa pihak lain menyatakan itu.

'Tidak' sebagai posisi pembuka dalam negosiasi harus dihayati oleh para negosiator, khususnya para pemula. Karena keliru memahami situasi ini, dapat berujung pada penurunan keyakinan bahwa dirinya memiliki kemampuan untuk menjadi negosiator yang baik.

Ketika menguraikan mengenai manajemen para negosiator, Bill Scott (1985:256) menyarankan empat faktor yang menjadi kriteria pemilihan negosiator. Salah satunya adalah ciri-ciri pribadi yang dimiliki. Ciri-ciri pribadi yang harus dimiliki seorang negosiator, menurut pendapatnya, cukup banyak. Di antaranya, negosiator harus: (1) bercitacita tinggi; (2) berpenampilan baik; (3) kreatif; (4) pandai mengemukakan pikiran; (5) pendengar yang baik; (6) bertekad maju; (7) pikiran terlatih; (8) mempunyai daya tahan terhadap frustasi tinggi; (9) tenang; dan (10) mempunyai keyakinan pada diri sendiri.

Scott berpendapat, negosiator harus memiliki aspirasi yang tinggi. Ciri ini mirip dengan yang dikemukakan Dawson bahwa negosiator itu harus berani meminta lebih banyak. Negosiator yang tidak berani meminta lebih tidak dapat menghasilkan transaksi dengan keuntungan yang besar karena dirinya tidak tega untuk menyatakan tuntutan atau aspirasi yang tinggi.

Negosiator, menurut Scott, harus berpenampilan baik karena penampilan akan memengaruhi proses negosiasi. Harus kreatif agar dapat mengusulkan berbagai ide untuk disepakati dan menghindarkan terjadinya deadlock. Orang yang tidak kreatif datang dengan hanya satu usulan. Ketika pihak lawan menolak usulan tersebut, maka kemacetan negosiasi tidak dapat dihindarkan.

Negosiator harus pandai mengemukakan pendapat. Pikiran itu bersifat abstrak. Hanya kemampuan mengemukakan pikiran yang dimiliki seseorang yang mengubahnya menjadi konkret melalui bahasa. Kelu dalam mengungkapkan pikiran dapat menimbulkan salah paham dan mengancam keberlangsungan komunikasi.

Negosiasi berjalan dalam bentuk komunikasi dua arah, sehingga ciri lain negosiator adalah kemampuannya menjadi pendengar yang baik sebagai modal untuk memahami keinginankeinginan pihak lain yang menjadi dasar perundingan dalam negosiasi. Kemampuan mendengar yang baik terutama diperoleh dari sikap untuk bersedia mendengarkan pihak lain.

Negosiator juga harus memiliki tekad untuk maju. Negosiator yang lemah cita-citanya akan terlalu cepat memberi konsesi kepada pihak lain dan memperoleh hanya sedikit dari pihak lain karena cepat puas dengan apa yang diperolehnya.

Scott menegaskan negosiator harus memiliki pikiran terlatih dalam menghadapi setiap situasi negosiasi. Dia harus memelihara kesadaran bahwa dirinya sedang berada dalam situasi negosiasi. Negosiator harus mahir dalam menggunakan strategi dan taktik negosiasi yang cocok dengan situasi yang dihadapi.

Negosiator harus memiliki daya tahan terhadap frustasi yang tinggi. Sifat ini sangat penting untuk dihayati negosiator karena negosiasi seringkali berjalan berlarut-larut dalam situasi yang keras atau kadang membosankan. Situasi demikian bukan saja disebabkan oleh masalah yang dinegosiasikan, akan tetapi pihak lain dapat mengarahkan proses negosiasi menjadi rumit dan tak mudah dipecahkan. Hanya negosiator yang memiliki daya tahan terhadap frustrasi yang tinggi dapat melewati situasi demikian dengan baik-baik saja.

Scott juga mengatakan bahwa negosiator yang baik itu memiliki sifat tenang. Sifat ini penting karena segala yang dikemukakan dalam proses negosiasi akan menjadi bahan kesepakatan, baik yang menguntungkan atau merugikan. Karena itu, negosiator yang tenang akan waspada agar tidak membuat kesepakatan yang merugikan di kemudian hari.

Akhirnya, Scott menjelaskan bahwa negosiator harus mempunyai sifat percaya kepada diri sendiri. Sifat ini sangat penting karena hanya negosiator yang percaya kepada dirinya sendiri yang akan berani melakukan negosiasi secara baik. Kepercayaan kepada diri sendiri membuat negosiator berani untuk meminta lebih dan berani 
melakukan penolakan terhadap pihak lain yang meminta terlalu tinggi. Lagi pula, negosiator sesungguhnya adalah orang-orang yang harus mandiri dan tidak mengandalkan pada orang lain dalam mencapai kesepakatan. Meskipun negosiasi acapkali dilakukan dalam kelompok, tapi negosiator (orang per orang) sejatinya harus memiliki keyakinan terhadap dirinya sendiri. Seirama dengan yang ditegaskan Dawson, seorang negosiator akan memiliki sikap yang mandiri apabila dia tidak memiliki keinginan yang tinggi untuk disukai orang lain.

\section{Kesimpulan}

Berdasarkan uraian di atas dapat dibuat disimpulkan:

(1) Pembahasan mengenai pribadi negosiator terbagi ke dalam tiga bagian, yaitu tentang karakteristik personal negosiastor, sikap negosiator, dan keyakinan negosiator. Terdapat lima karakteristik yang harus dimiliki seorang peribadi negosiator, yaitu: berani menggali informasi lebih banyak, sabar bertahan lebih lama daripada negosiator lawan, memiliki integritas untuk menekan agar tercipta solusi menang-menang, berani meminta lebih banyak dari yang diharapkan, serta bersedia menjadi pendengar yang baik. Selain itu, negosiator juga mesti mengembangkan sikap yang cocok untuk bernegosiasi. Di antaranya, dia harus siap hidup dalam ambiguitas, memiliki semangat untuk bersaing, serta tidak memiliki keputusan yang tinggi untuk disukai orang lain. Hal lain yang harus melengkapi kepribadian negosiator adalah keyakinan mengenai bagaimana negosiasi berjalan. Seorang negosiator harus yakin bahwa negosiasi merupakan hubungan dua arah; apabila dirinya merasa ada dalam tekanan, maka pihak lain yang bernegosiasi dengannya merasakan hal serupa. Negosiator harus yakin bahwa negosiasi merupakan proses yang berjalan berdasarkan aturan tertentu, sehingga dapat direncanakan dan hasilnya dapat diperkirakan. Selain itu, negosiator harus yakin bahwa 'tidak' merupakan posisi pembuka negosiasi bukan penolakan.

(2) Dengan uraian mengenai pribadi negosiator diharapkan mereka yang menyiapkan diri sebagai negosiator profesioanal akan memiliki pengetahuan dan rasa percaya diri yang mentap untuk terus membina diri dan meningkatkan kecakapan profesionalnya sebagai negosiator yang profesional yang mempu menjalankan negosiasi dengan baik dan profesional.

\section{Daftar Pustaka}

Cohen, Herb. 1980. Negosiasi. Jakarta: PT. Pantja Simpati.

Lewicki, J. et al. 2003. Negotiation. New York: McGraw-Hill.

Purwadarminta, 1997. Kamus Umum Bahasa Indonesia. Jakarta: Departemen Pendidikan Balai Pustaka.

Dawson, Roger. 2002. Secrets of Power Negotiating, Rahasia Sukses Seorang Negosiator Ulung. Jakarta: PT. Gramedia Pustaka Utama.

Fisher, Roger, et al. 2000. Getting to Yes: Teknik Berunding Menuju Kesepakatan tanpa Memaksakan Kehendak. Penerjemah Daniel Haryono dan Gloria Situmorang. Jakarta: Yayasan Obor Indonesia.

Pease, Allan. 1996. Bahasa Tubuh: Bagaimana Membaca Pikiran Seseorang melalui Gerak Isyarat. Jakarta: Penerjemah Arum Garyati. Penerbit Arcan.

Tubbs, Stewart L., dan Sylvia Moss. Human Communication: Prinsip-PrinsipDasar. Buku Pertama, Penerjemah Deddy Mulyana dan Gembirasari. Bandung: PT Remaja Rosdakarya.

Scott, Bill. 1985. Strategi dan Teknik Negosiasi. PT Pustaka Binaman Pressindo, Jakarta. 